\title{
Factors Affecting Commercialisation of Indigenous Chickens in Swaziland
}

\author{
Bongani J. Siyaya \\ P.O. Box 4305, Manzini, M200, Swaziland \\ Micah B. Masuku (Corresponding Author) \\ Department of Agricultural Economics and Management, P. O. Luyengo \\ Luyengo. M205. University of Swaziland, Swaziland.
}

Tel: 268-76-026-557Ｅmail: mbmasuku@uniswa.sz

Received: July 17, 2013 Accepted: August 3, 2013

doi:10.5296/jas.v1i2.4016 URL: http://dx.doi.org/10.5296/jas.v1i2.4016

\begin{abstract}
About $90 \%$ of rural households in Swaziland keep indigenous chickens and the government of Swaziland, through the Ministry of Agriculture, implemented a commercialisation programme for indigenous chickens between 2008 and 2009 as a move towards ensuring food security and income generation. The purpose of the study was to conduct an analysis of the factors affecting the commercialising indigenous chickens in Swaziland. Specifically the study sought to; estimate sales rate, identify factors affecting sales rate and further identify constraints to commercialisation of indigenous chickens. The study used a descriptive quantitative design. Using a stratified random sample 147 indigenous poultry farmers were sampled from a population 729 farmers who trained on commercialisation of indigenous chickens in the four regions of Swaziland. Data were collected by the use of personal interviews with the aid of a structured questionnaire. Descriptive statistics such as means, mode and frequencies were used to estimate sales rate and analyse constraints to commercialisation, whilst a Tobit regression analysis was used to analyse factors affecting commercialisation of indigenous chickens. The results indicated a Pseudo- $\mathrm{R}^{2}$ of 0.88 implying that $88 \%$ of the variation in the model was due to the explanatory variables. Prices of alternative products, quantity of chickens sold, quantity of chickens consumed significantly $(\mathrm{p}<0.01)$ affected sales rate. Supplementary feed also significantly $(p<0.10)$ affected the rate to commercialise. The results further indicate that farmers were constrained by: high disease outbreak; lack of fencing and housing; high feed costs; lack of markets; low productivity; lack of credit access; poor growth and maturity and
\end{abstract}


low market prices. It is recommended that farmers organize themselves into cooperatives or associations to take advantage of discounts when purchasing feed.

Key words: Commercialisation, Indigenous chickens, Tobit regression.

\section{Introduction}

Agriculture is traditionally the backbone of Swaziland's economy and a major source of employment for rural households with over $70 \%$ of the population relying on this sector for their incomes. The diverse agricultural activities that take place in the country include the production of sugarcane, citrus fruit, and maize and other cereal crops, cotton, forestry and livestock. Swaziland's agricultural sector is divided into two sub-sectors namely; formal and informal or traditional. Traditional or subsistence farming is mainly practiced on Swazi Nation Land (SNL), which is about 60 percent of land in Swaziland (MOA, 2012). It is acquired in terms of Swazi law and custom. While agricultural activities in these areas may be carried out for subsistence purposes only, efforts are being made to encourage SNL farmers to practise commercial agriculture (Thompson, 2012). According to Thompson (2012), the formal agriculture category embraces the large sugar and citrus estates, forestry and other undertakings on individual tenure farms (ITFs) which generate foreign exchange earnings. It covers about 40 percent of the land in Swaziland.

Most indigenous chickens in Swaziland are organically produced. There is a strong linkage between organically produced commodities and nutrition or health (Times of Swaziland, 24 June 2009). Undoubtedly, most consumers of white meat prefer indigenous chicken, including their eggs. It is also worth noting that broilers are not substitutes to indigenous chicken on the competition landscape in terms of taste, preference, and quality. It is important to note that there is lack of statistics pertaining to production of indigenous chickens. Addressing the lack of organized information challenge would assist to address the following particularly in the production of indigenous chickens: market size and spread; consumption or demand pattern; cost of production (from day one to point of sale), and point of sale (from six months or one year). There are many factors that impact on the commercialisation of indigenous chickens such that it is possible to get diverse outcomes. This study therefore, seeks to close the information gap in terms of factors influencing commercialisation of indigenous chickens in Swaziland.

The purpose of the study was to conduct an analysis of factors affecting commercialisation of indigenous chickens by smallholder farmers in Swaziland. The specific objectives of the study were to: (1) Characterise indigenous poultry farmers; (2) Identify factors affecting commercialisation of indigenous chickens; and (3) Identify constraints encountered by farmers in commercialising indigenous chickens.

\section{Literature Review}

\subsection{Poultry Production in Swaziland}

The Ministry of Agriculture (MOA) through the poultry section promotes poultry production in Swaziland with emphasis on broiler production, egg production and the production of 
indigenous chickens. MOA (2012) reported that indigenous poultry production is a fast growing animal production industry in the country. The indigenous poultry industry has been encouraged to commercialise in order to improve the quality of life for the people in terms of; food security, poverty alleviation, income generation and as a drive towards self-sufficiency in poultry and poultry products. According to Thompson (2012), the livestock development policy emphasizes on the commercialisation of cattle, poultry and pigs in particular, as well as goats in order to create employment and attain food security in the rural areas. This initiative includes encouraging farmers to extend beyond rearing livestock and move on to the meat processing level. With encouragement from government and commercial operations, poultry production is one of the fastest growing agricultural subsectors, providing many income-generating opportunities.

The most common type of poultry kept in a number of homesteads is chicken (Gallus domesticus) species (Masuku, 2011). Many farmers keep chickens for meat consumption purposes. This has been more advantageous because it has been easy to manage them in terms of feeding and treatment. In the past chickens were exposed to scavenging or free range systems for feed and received little supplementary feeding. There was no provision for housing, thus they were characterized by low input and low output. Masimula (2004) noted that surveys indicated that $91 \%$ of families in rural areas of Swaziland mostly raise chickens. In Swaziland, indigenous chickens are kept through subsistence farming practices by almost all the homesteads, with a minimum of at least five birds per family (Thwala, 2012). Like in all developing countries, Swazi farmers use family labour and occasionally use commercially available feeds. The chickens are kept under scavenging production systems with limited application of management interventions to improve flock productivity. Thwala (2012) noted that indigenous poultry production is of great importance to smallholder Swazi farmers, but they face the challenge of improving productivity of their flock, which could benefit them financially and promote food security as well as achieve market potential.

The indigenous chickens' production guide developed by the Ministry of Agriculture in Swaziland indicates that the basic requirements for successful chickens' enterprise are housing, feeding, vaccination, water provision, marketing and extension service (MOA, 2012). Domestic indigenous chickens are constrained by disease, lack of housing and insufficient feed. As a result, the productivity of these chickens is usually low. Addressing these constraints tend to increase production significantly. Under the traditional systems, indigenous chickens are rarely provided with housing such that they are exposed to predators, thieves, stress and adverse weather conditions. A good chicken house should protect the chickens from predators, thieves, and adverse weather conditions. It should also be easy to clean, well ventilated and should have adequate space for roosting, brooding, feeding and running around (MOA, 2012). Indigenous chickens use natural feed sources such as insects, worms, weeds left-over's and grasses although some farmers may provide supplementary feeding. Supplementary feed given twice a day from whole grain, mixed fowl food, hominy chops and rice husks are usually recommended. Clean and cool water is essential for birds of all ages. 


\subsection{Commercialisation of Indigenous Chickens In Swaziland}

According to Kunene Thembinkosi (Personal Communication, October 9, 2012) the commercialisation of indigenous poultry programme was launched by the Ministry of Agriculture in the year 2008/9 as an initiative towards food security and poverty eradication in the country. This came as a result of high feed costs due to the global economic meltdown rendering production costs of exotic chickens extremely high. He further pointed out that the launch was done before the poultry officers could be trained on indigenous poultry production as local institutions did not offer courses on the subject. Kunene (2012) also noted that there was no detailed and complete study done on indigenous chickens in Swaziland except for production guides produced by Swaziland Agricultural Development Enterprises (SWADE), Techno-serve and Ministry of Agriculture (MOA). Dlamini (2012), the Minister of Agriculture, as quoted by the Swazi Observer (June 8, 2012), noted that most small-holder indigenous poultry farmers were commercialising the industry. He further noted that this was one endeavor to mitigate food insecurity in the country and to create wealth for the farmers because indigenous chickens tend to generate more revenue. It was further indicated that the market for indigenous chickens is booming all over the country and throughout the year.

\subsection{Factors affecting Commercialisation of Agriculture}

According to Von Braun et al. (1994) commercialisation of smallholder farming can achieve its objectives and bring about the required benefits to the poor and rural based households when certain factors influencing its success are brought under control. He further pointed out that there are several exogenous factors that determine commercialisation and these include population change, availability of new technologies, infrastructure and market creation, and macroeconomic and trade policies.

A study conducted by Martey, Ramatu, and Kuwornu (2012) analysing the promotion of commercialisation of smallholder farmers in Ghana, the trends in maize and cassava production by farm households. The study found that output price, farm size, households with access to extension services, distance to market and market information significantly influenced the extent of commercialisation. Goitom (2009) in a study analysing household and farm characteristics determining the level of commercialisation of smallholder farmers in Ethiopia dealt with the degree of participation in the output market for those smallholders who had already participated in the output market. The study attempted to identify reasons for some farmers to sell more and others less (in value terms). The multivariate linear regression analysis was used to identify the relationship between the gross value of all crops sold and the socio-economic characteristics of households.

\section{Methodology}

\subsection{Research Design}

The study used a descriptive quantitative design. It sought to identify factors affecting commercialisation of indigenous chickens and further identified constraints faced by farmers in the commercialisation of indigenous chickens. 


\subsection{Sampling and Data Collection}

The target population for the study was 729 active smallholder farmers of indigenous chickens in Swaziland that have been trained by the Ministry of Agriculture on the commercialisation programme. A sample of 147 farmers was sampled using a stratified random sampling technique. Data were collected using personal interviews with an aid of a structured questionnaire. The questionnaire was reviewed by experts in the Department of Agricultural Economics and Management to establish content and face validity. Questionnaires were further pretested using farmers who were not part of the sample and responses were used to construct the final questionnaire.

\subsection{Data Analysis}

Descriptive statistics using frequencies and means were used to describe the characteristics of the farmers, while the Tobit regression model was used to identify the factors of commercialisation of indigenous chickens. Descriptive statistics such as mode, means and frequencies were used to identify and rank the constraints to commercialisation of indigenous poultry production in Swaziland. The analysis was conducted using STATA version 10 and statistical package for social sciences (SPSS version 17).

\subsection{Econometric Model}

The level and magnitude of commercialisation among smallholder farmers of indigenous chickens was measured using sales rate. Sales rate for indigenous chickens is computed as a percentage of total output that has been sold, whose values ranges between $0 \%$ (no commercialisation) and $100 \%$ (fully commercialised).

Sales rate $=($ Quantity Sold/ Quantity produced $)$ X 100

The Tobit regression model was used to explain the relationship between the dependent variable (sales rate) and explanatory variables (levels of inputs) where yield or units of chickens produced is a function of inputs. The model was specified as;

$$
y_{i}^{*}=X_{i} \beta+\varepsilon_{i}
$$

Where: $y_{i}{ }^{*}$ is a latent variable that is generated by a classical linear regression model, and $\beta$ is the corresponding vector of explanatory variables. The model errors $\varepsilon_{i}$ are assumed to be independent, $\mathrm{N}\left(0, \sigma^{2}\right)$ distributed, conditional on the $X_{i}$. The observed $y_{i}$ is defined as 1 if $y_{i}{ }^{*}>$ 0 and 0 if $y_{i} * \leq 0$. The Tobit regression model used in the study is presented as follows:

$\mathrm{Y}_{\mathrm{i}}{ }^{*}=\alpha+\beta_{1} \mathrm{X}_{1}+\beta_{2} \mathrm{X}_{2}+\beta_{3} \mathrm{X}_{3}+\beta_{4} \mathrm{X}_{4}+\ldots \ldots .{ }_{19} \mathrm{X}_{19}+\mu$

Where:

$\alpha=$ intercept term

$\mathrm{Y}_{\mathrm{i}} *=$ sales rate (proportion of chicken units sold to total stock produced per year); used as proxy for commercialisation;

$$
\mathrm{X}_{1}=\text { Farmer's age (years); }
$$


$\mathrm{X}_{2}=$ Farmer's level of formal education (years);

$\mathrm{X}_{3}=$ Farmer's gender, a dummy variable (1for female and 0 for male);

$\mathrm{X}_{4}=$ Marital status of the farmer $(1=$ single, $2=$ married, $3=$ divorced, $4=$ widowed $)$;

$\mathrm{X}_{5}=$ Household size (no of persons);

$\mathrm{X}_{6}=$ Farmer's off-farm income $(1=$ yes, $0=$ no $)$;

$\mathrm{X}_{7}=$ Experience of the farmer in the production of indigenous chickens (years);

$\mathrm{X}_{8}=$ Provision of supplementary feed $(1=$ yes; $0=$ no $)$;

$\mathrm{X}_{9}=$ Total cost of feed used (Emalangeni/ year);

$\mathrm{X}_{10}=$ Costs of vaccination in Emalangeni per year;

$\mathrm{X}_{11}=$ Units of chickens stock sold the previous year (number sold);

$\mathrm{X}_{12}=$ Total mortalities recorded the previous year (number of deaths);

$\mathrm{X}_{13}=$ Market price per unit of live chicken in Emalangeni (E);

$\mathrm{X}_{14}=$ Prices of alternative products (broiler meat, pork, beef) in Emalangeni (weighted average, E);

$\mathrm{X}_{15}=$ Credit availability for farmers $[1=$ Yes, $0=$ No $]$;

$\mathrm{X}_{16}=$ Farmer training in indigenous chicken production $[1=\mathrm{Yes}, 0=\mathrm{No}]$;

$\mathrm{X}_{17}=$ Access to extension services in farming; $[1=$ Yes, $0=$ No $]$;

$\mathrm{X}_{18}=$ Losses in number of live chicken units due to theft (number stolen);

$\mathrm{X}_{19}=$ Chicken units consumed by the family per year (number);

$\mu=$ Error term;

$\beta_{\mathrm{i}}=$ Coefficients of the explanatory variable.

3.4.1 Explanation of the variables and a priori expectations

Farmer's Age $\left(\mathrm{X}_{1}\right)$ : The older the farmer, the more likely to it for him or her to have more experience to produce more chickens hence, the higher potential to sell. Older farmers are expected to have more capital assets thus, higher sales rate (increased commercialisation).

Formal Education $\left(\mathrm{X}_{2}\right)$ : This refers to the level at which the farmer exited school. Higher levels of formal education are positively and significantly associated with higher sales rates, as the farmer may understand business concepts batter.

Farmer's gender $\left(\mathrm{X}_{3}\right)$ : This is a dummy variable for either male or female farmers. Male farmers are expected to be highly commercialised as they are likely to own more land, more capital assets and financially independent. 
Marital status $\left(\mathrm{X}_{4}\right)$ : Being married is positively associated with being mature and experienced in farming and owning indigenous chickens. Married people are more likely to commercialise indigenous chickens.

Household size $\left(\mathrm{X}_{5}\right)$ : The higher the number of persons per household the higher the consumption. Increase in household size is significantly and negatively associated with commercialisation.

Farmer's off-farm income $\left(\mathrm{X}_{6}\right)$ : If a farmer has wage employment or other source of income, he or she has more potential to commercialise. Off-farm income is positively related to commercialisation.

Farmer's experience $\left(\mathrm{X}_{7}\right)$ : The number of years a farmer has been involved in the production of indigenous chickens positively influence his management expertise and skills, and his potential commercialise. Experience is positively and significantly related to higher sales rate.

Supplementary feed $\left(\mathrm{X}_{8}\right)$ : When chickens are given supplementary feed, they are likely to produce more, grow faster and mature faster. Provision of supplementary feed is positively related and significant to commercialisation.

Feed cost $\left(\mathrm{X}_{9}\right)$ : The total amount of money paid for buying supplementary feed. It is negatively associated to sales as it increases production costs but reduce commercialisation.

Vaccination costs $\left(\mathrm{X}_{10}\right)$ : Vaccination costs are negatively related to commercialisation as they increase total costs of production, thus reducing profit.

Stock number sold $\left(\mathrm{X}_{11}\right)$ : Total number of chickens sold from the total produced. It is expected to significantly and positively influence sales rate of indigenous chickens. The higher the quantity of stock sold the higher the sales rate.

Mortalities $\left(\mathrm{X}_{12}\right)$ : This refers to the total number of stock that died the previous year. Mortalities reduce total stock size and thus reduce the number of chickens that can be sold from the flock. Significant though, mortalities are negatively associated with sales rate.

Market price $\left(\mathrm{X}_{13}\right)$ : The price at which each unit of chicken is sold. Demand for food products is inelastic. If price increases demand is not affected. Market price is significantly and positively associated with increased sales.

Prices of alternative products $\left(\mathrm{X}_{14}\right)$ : The substitute goods for indigenous chickens are broilers, beef, pork, wors and turkey. The weighted average price of these products will significantly but negatively influence the production of indigenous chickens.

Credit Availability for farmers $\left(\mathrm{X}_{15}\right)$ : This refers to provision of credit or loans to indigenous chickens' producers for purchase of fence, house material and feed. It is expected that farmers who get credit from finance institutions have significant relationship to commercialisation. It is expected to be a negative relationship. 
Farmer training $\left(\mathrm{X}_{16}\right)$ : This relates to training farmers receive on the production of indigenous chicken and this is expected to positively influence the commercialisation of the chickens. Trained farmers improve their skills and expertise on the management of indigenous chickens.

Extension services $\left(\mathrm{X}_{17}\right)$ : This is assistance and advice received by farmers from agricultural extension officers. Extension services enable farmers to manage their chickens well, resulting to higher production rates; hence a higher proportion of the stock of chickens may be sold.

Stolen chickens $\left(\mathrm{X}_{18}\right)$ : This is loss to production due to theft. It is expected to have a negative relationship to sales rate.

Consumption (X19): This is the number of stock that has been consumed by the family. The higher the number of chickens consumed, the lesser the number of chickens to be sold. This is expected to have a negative relationship to sales rate.

\section{Results and Discussion}

\subsection{Characteristics of Respondents}

Table 1 shows the number of respondents interviewed according to age, gender, level of formal education and marital status. Of the 147 respondents that were interviewed, 66\% were females and $34 \%$ were males. This is because in most homesteads, males are always at work and not at home and most of the farming activities are done by women. Therefore, the majority of indigenous chickens' farmers were women. Most of the men were those that had retired from work, thus keeping indigenous chickens in order to earn income. The results in Table 1 also shows that $26 \%$ of the respondents were farmers who were above 60 years old. This includes the group of farmers who were pensioners, and have retired from employment. Twenty one percent of the respondents were 50 to 59 years old and above, while $27 \%$ had a range of 40 to 49 years old. Twenty four percent of the farmers were aged 30 to 39 years old and only $2 \%$ of the respondents were aged less than 30 years.

According to the results of the descriptive statistics in Table 1, only $11 \%$ of the respondents were single, while $75 \%$ were married and $14 \%$ were widows. The results show that only $7 \%$ of the respondents did not have formal education, while $31 \%$ of them attended up to primary level of formal education and 35\% reached secondary. Twenty four percent of the respondents completed high school and $3 \%$ had tertiary education.

Table 1. Characteristics of Respondents

\begin{tabular}{|l|l|l|}
\hline Variable & Frequency & Percentage \\
\hline Gender \\
\hline Males & 97 & 66 \\
\hline Females & 50 & 34 \\
\hline Age & \\
\hline $20-29$ years & 3 & 2 \\
\hline $30-39$ years & 36 & 24 \\
\hline $40-49$ years & 39 & 27 \\
\hline $50-59$ years & 31 & 21 \\
\hline
\end{tabular}




\begin{tabular}{|l|l|l|}
\hline Above 60 years & 38 & 26 \\
\hline Marital Status & \multicolumn{2}{|l|}{} \\
\hline Single & 16 & 11 \\
\hline Married & 110 & 75 \\
\hline Divorced & 0 & 0 \\
\hline Widowed & 21 & 14 \\
\hline Educational Level \\
\hline Primary & 45 & 31 \\
\hline Secondary & 52 & 35 \\
\hline High School & 35 & 24 \\
\hline Tertiary & 5 & 3 \\
\hline None & 10 & 7 \\
\hline
\end{tabular}

\subsection{Description of the Variables}

Table 2 indicates that the average age of the farmers of indigenous chickens was 49 years. This is because the industry is dominated to a greater extent by adults who are the home owners and most of them are pensioners or retired. The youngest farmer was 28 years old and the oldest was 74 years old. The farming experience of the farmers used was 12 years on average, ranging from zero years to 50 years of farming experience.

As shown in Table 2, the average household size was 5 persons; with a range of 1 person to 11 persons per household. All farmers of indigenous chickens' were found on Swazi Nation Land (communal land tenure). The average land size allocated per farmer was 3 hectares (ranging from 0.5 ha to 10 ha). Stock size the previous year (2012) varied from 6 chickens to over 300 chickens with a mean of 71 chickens. The current year stock size showed an overall significant decline to a mean of 41 chickens per farmer due to prevalent challenges, especially the cost of feed. Losses of chickens due to theft stood at about 4 chickens per farmer and chickens that died due to diseases, predators and weather averaged at 28 chickens per farmer per year.

Vaccination costs per farmer averaged at E87.16 per year; ranging from zero for subsistence farmers who used locally available medicines to control diseases, and was E505.00 for more commercialised farmers. Almost all of the farmers (86\%) interviewed provided their chickens with supplementary feed and the average feed cost was at E2459.14 per year. Subsistence farmers spent at least E200 on feed, while commercialised farmers spent E9000.00 on feed per year. The cost of breeding stock (hen and cock) was E66.00 on average, while the most expensive cock was bought at E200.00. The maximum price for a hen of E120.00 was reported. The average price of a cock was at E78.00 while the average price of a hen was E54.00. The average chicken price at the market was E60.00, with a range of E35.00 to E150 maximum per bird. Flea markets to which farmers sell their chickens were located $22 \mathrm{~km}$ away from the farmers, with a range of $1 \mathrm{~km}$ to $95 \mathrm{~km}$ away. Farmers far away from flea markets complained of high transport costs that reduced their returns as they had to hire cars to the flea market. Even though most farmers were not working, about 87 percent had off-farm income from children' support and husbands support as most farmers were found to be women who had no formal employment, but housekeepers. 
Table 2. Description of the Variables used in the Study

\begin{tabular}{|l|l|l|l|l|}
\hline Variable & Mean & Std. Dev. & Min & Max \\
\hline Farmer's age (years) & 49.453 & 12.394 & 28 & 74 \\
\hline Farming experience (years) & 12.672 & 10.835 & 1 & 50 \\
\hline Commercial farming exp. (years) & 2.9297 & 2.498 & 0 & 21 \\
\hline Household size (persons) & 5.472 & 2.214 & 1 & 11 \\
\hline Vaccination costs (E)* & 87.164 & 98.345 & 0 & 505 \\
\hline Total land size (ha/farmer) & 2.949 & 1.656 & .5 & 10 \\
\hline Land size used by chickens (ha) & 2.073 & 1.129 & .4 & 6 \\
\hline Land tenure (1for SNL; 0 for TDL) & 1 & 0 & 0 & 1 \\
\hline Supplementary feed $(1=$ yes; $0=$ no) & 0.870 & 0.338 & 0 & 1 \\
\hline Current stock size (number) & 41.898 & 25.634 & 10 & 115 \\
\hline Previous years' stock size (number) & 71.266 & 53.154 & 6 & 316 \\
\hline Previous year feed cost (E) & 2459.141 & 1796.683 & 200 & 9000 \\
\hline Off-farm income (1= yes; $0=$ no) & 0.870 & 0.338 & 0 & 1 \\
\hline Breeding stock price (E) & 65.992 & 30.523 & 0 & 200 \\
\hline Market price (E) & 59.922 & 19.042 & 35 & 150 \\
\hline Extension service (1 = yes; 0 = no) & 0.5 & 0.502 & 0 & 1 \\
\hline Cooperative membership (1= yes; 0= no) & 0.712 & 0.454 & 0 & 1 \\
\hline Production training (1= yes or 0 = no) & 1 & 0.178 & 0 & 1 \\
\hline Credit access & 0.028 & 0.164 & 0 & 1 \\
\hline Flea market distance (km) & 22.27344 & 15.41485 & 1 & 95 \\
\hline Stolen chickens (number) & 4.425197 & 6.533819 & 0 & 36 \\
\hline Mortality of chicken (number) & 27.89063 & 31.87901 & 0 & 198 \\
\hline Sales rate (percentage proportion) & 0.3412578 & 0.2704177 & 0 & 1 \\
\hline
\end{tabular}

$* 1 \mathrm{US} \$=9.8$ Emalangeni (E) (July, 2013)

All the farmers agreed that they had received training on indigenous chickens through poultry officers from the regional agricultural offices and from some parastatal organizations such as SWADE. About $50 \%$ of the farmers reported to be receiving extension service in their areas, the others claimed they never received extension officers' assistance. Seventy one percent of the farmers interviewed were members of cooperatives or were organised in some way to easily access production training and market information. Less than $3 \%$ of the farmers got credit from parastatals such as SWADE and nongovernmental organisations such as World vision. The mean sales rate in the study was 0.34 .

\section{Categorization of Respondents by Sales Rate}

Of the 147 farmers of indigenous chickens who participated in the study as shown in Table 3 , $48 \%$ were found to be practicing subsistence farming (sales rate below 25\%), $20 \%$ were found to be transitional farmers (sales rate between 0.25 and 0.50 ) and $32 \%$ of the respondent were found to practice commercial farming (sales rate above 0.5 ). 
Table 3. Categorization of Respondents by Sales Rate

\begin{tabular}{|l|l|l|l|}
\hline Sales Rate & Categorization of farmers & Number of Farmers per Category & Percentage \\
\hline $0-0.249$ & Subsistence & 70 & 48 \\
\hline $0.250-0.499$ & Transition & 30 & 20 \\
\hline $0.500-1.000$ & Commercial & 47 & 32 \\
\hline Total & 147 & 100 \\
\hline
\end{tabular}

\subsection{Factors Affecting Commercialisation of Indigenous Chickens}

The Tobit regression model was used in analysing the effect of the factors affecting commercialisation of indigenous chickens. The results of the Tobit regression are given on Table 4. The results indicate that the level of commercialisation of indigenous chickens was affected $(\mathrm{p}<0.01)$ by price of alternative products, quantity of birds sold, quantity of birds consumed. Supplementary feed had a negative but significant $(\mathrm{p}<0.10)$ relationship with sales rate. Prices of alternative products such as broiler meat, beef and chicken were significantly $(\mathrm{p}<0.01)$ related to commercialisation of indigenous chicken production. When prices of the alternative products (beef, pork, broilers and turkey) are increased by E1.00; the sales rate of indigenous chickens increases by 0.012. The number of chickens sold had a significant $(\mathrm{p}<$ 0.01 ) effect on the sales rate. Increasing the number of chickens sold per year by one unit would increase the sales rate by 0.006 .

According to the results in Table 4, the number of chickens consumed per year by the family significantly $(p<0.01)$ decreases the sales rate of indigenous chickens. Though this significant relationship was not expected, when consumption increases by one unit, it results into a 0.003 decrease in sales rate. Provision of supplementary feed to chickens was positively associated with a significant $(\mathrm{p}<0.10)$ increase in sales rate. Actually, sales rate for farmers who provide supplementary feed declines by 0.15 compared to that of farmers who do not provide supplementary feed.

Table 4. Factors Affecting Commercialisation of Indigenous Chickens in Swaziland.

\begin{tabular}{|l|l|l|l|l|}
\hline Variable Name & Coefficient & Standard Error & $\mathrm{t}-$ value & $\mathrm{P}-$ value \\
\hline Gender $(1=$ female or $0=$ male) & 0.030 & 0.046 & 0.65 & 0.520 \\
\hline Farmer age (years) & 0.001 & 0.002 & 0.73 & 0.469 \\
\hline Marital Status & -0.040 & 0.027 & -1.47 & 0.144 \\
\hline Education Level & 0.018 & 0.020 & 0.86 & 0.390 \\
\hline Household size (persons) & 0.008 & 0.010 & 0.87 & 0.387 \\
\hline Vaccination cost (E) & -0.000 & 0.000 & -1.61 & 0.110 \\
\hline Supplement feed $(1=$ yes, $0=$ no) & $-0.147 *$ & 0.064 & -2.27 & 0.025 \\
\hline Total Feed cost $(\mathrm{E})$ & -0.000 & 0.000 & -0.96 & 0.340 \\
\hline Off farm income $(1=$ yes, $0=$ no) & 0.009 & 0.069 & -0.12 & 0.901 \\
\hline Market price $(\mathrm{E})$ & 0.000 & 0.001 & 0.14 & 0.891 \\
\hline Price of alternative products $(\mathrm{E})$ & $0.012 * * *$ & 0.004 & 3.46 & 0.001 \\
\hline Extension service $(1=$ yes, $0=$ no) & -0.054 & 0.043 & -1.24 & 0.219 \\
\hline Training $(1=$ yes, $0=$ no) & 0.115 & 0.120 & 0.96 & 0.341 \\
\hline
\end{tabular}




\begin{tabular}{|l|l|l|l|l|}
\hline Credit access $(1=$ yes, $0=$ no) & 0.122 & 0.126 & 0.97 & 0.333 \\
\hline Quantity sold (number) & $0.006^{* * *}$ & 0.001 & 9.46 & 0.000 \\
\hline Quantity consumed (number) & $-0.003^{* * *}$ & 0.001 & -3.67 & 0.000 \\
\hline Mortalities per year (number) & -0.000 & 0.001 & -0.17 & 0.868 \\
\hline Quantity stolen per year (number) & 0.001 & 0.003 & 0.31 & 0.757 \\
\hline Experience (years) & 0.001 & 0.002 & 0.40 & 0.692 \\
\hline Constant & -0.250 & 0.248 & -1.01 & 0.316 \\
\hline
\end{tabular}

Pseudo $\mathrm{R}-$ squared $=0.8777 ; * * *, * *, *=$ significant at $1 \%, 5 \%$ and $10 \%$ respectively.

The results from Table 5 show that the most common disease of indigenous chickens in the study area was fowl pox as reported by $95 \%$ of the respondents interviewed, followed by Newcastle Disease by $49 \%$ of the respondents. Respiratory diseases of poultry were rated third most important poultry disease by respondents (33\%). Twenty percent of the respondents rated the problem of external parasites fourth, while the diseases that cause paralysis of limbs in poultry were ranked fifth by $17 \%$ of the respondents. Twelve percent of the farmers experienced death of their stock due to swelling of the liver and $9 \%$ lost their chickens due to knee problems.

Table 5. Common Diseases of Indigenous Chickens as Reported by Respondents

\begin{tabular}{|l|l|l|}
\hline Diseases & Frequency & Percentage \\
\hline Fowl Pox & 140 & 95 \\
\hline New Castle & 69 & 47 \\
\hline Swelling of liver & 17 & 12 \\
\hline Respiratory diseases & 48 & 33 \\
\hline Knee problem & 13 & 9 \\
\hline Limb (wings/ legs) Paralysis & 25 & 17 \\
\hline Lice and mites & 30 & 20 \\
\hline
\end{tabular}

Farmers used both traditional medicines and modern vaccinations to control diseases. Most farmers were taught during their trainings to use fowl pox mix during the rainy months (December and January) to control fowl pox. Consumix, fosbac and sulfazine were used as broad spectrum vaccinations against worms. Farmers also mentioned that they vaccinated their stock three times a year against new castle disease (April, August and December) using La sota vaccine. Indigenous plants used to control poultry diseases and parasites included the aloe solution, snuff, sisal solution, inkalane and sinhlonhlwane. Some farmers used old sump oil to control fowl pox. Carbadust and Blue death were commonly used pesticides in the control of lice and mites in poultry.

\subsection{Constraints to Commercialisation of Indigenous Chickens in Swaziland}

Respondents were asked to indicate constraints they faced in their endeavour to commercialise indigenous chickens. They were asked to list the constraints in order of importance starting with the most important (ranked 1) and least important (ranked 10). The results are presented in Table 6 . The results show that $76 \%$ of the respondents reported that the main constraints were 
high disease outbreak among the poultry flocks. Lack of training and urbanisation of the area were also ranked 1 (most important) but by less than $1 \%$ of the total respondents. Sixty two percent of the farmers included in the study ranked the lack of fencing material the second most important constraint in indigenous chicken production, whilst $46 \%$ of the respondents also ranked the lack of housing and equipment as second. Chickens need a fenced off area to be protected from predators and thieves and housing to protect them from weather. Also ranked second were the lack of brooding equipment and lack of incubators or hatcheries, but by less than one percent of the sample.

Table 6. Constraints of Commercialisation of Indigenous Chickens in Swaziland ( $n=147)$.

\begin{tabular}{|l|l|l|l|l|l|l|}
\hline Description of Constraint & Frequency & Percent & Min. Value & Max. value & Range & Modal Value \\
\hline Lack of fencing & 91 & 62 & 1 & 10 & 9 & 2 \\
\hline High feed costs & 49 & 33 & 1 & 8 & 7 & 3 \\
\hline Lack of house/equip & 68 & 46 & 1 & 6 & 5 & 2 \\
\hline High disease outbreak & 112 & 76 & 1 & 9 & 8 & 1 \\
\hline High mortality rates & 56 & 38 & 1 & 10 & 9 & 10 \\
\hline Slow growth/ maturity & 58 & 39 & 1 & 10 & 9 & 7 \\
\hline Low market prices & 76 & 51 & 1 & 10 & 9 & 9 \\
\hline Lack of markets & 83 & 56 & 1 & 6 & 5 & 4 \\
\hline Markets inaccessible & 78 & 53 & 1 & 10 & 9 & 3 \\
\hline Predators & 33 & 22 & 1 & 10 & 5 & 4 \\
\hline Theft of chickens & 79 & 54 & 1 & 10 & 9 & 8 \\
\hline Urbanization & 2 & 0.01 & 1 & 2 & 1 & 1 \\
\hline Low productivity & 2 & 0.02 & 5 & 8 & 3 & 5 \\
\hline Lack information & 19 & 13 & 2 & 7 & 5 & 3 \\
\hline Poor vaccination & 2 & 0.01 & 1 & 3 & 8 & 6 \\
\hline Lack of training & 11 & 0.07 & 1 & 4 & 3 & 1 \\
\hline Loss of eggs & 5 & 0.03 & 2 & 6 & 4 & 3 \\
\hline Mites and lice & 2 & 0.01 & 4 & 5 & 1 & 4 \\
\hline Brooder & 5 & 0.03 & 2 & 5 & 3 & 2 \\
\hline Water & 5 & 0.03 & 1 & 6 & 5 & 6 \\
\hline Lack of incubators & 4 & 0.03 & 2 & 7 & 5 & 2 \\
\hline Lack of credit & 5 & 0.03 & 3 & 3 & 4 & 6 \\
\hline Poor market access & 13 & 0.09 & 1 & 9 & 8 & 6 \\
\hline Defaulting Traders & 2 & 0.01 & 5 & 7 & 2 & 5 \\
\hline & & & & & \\
\hline
\end{tabular}

* Rank 1 = Most important; 10 = least important

Thirty three percent of the respondents ranked the lack of fencing as third most important constraint, together with market inaccessibility due to lack of transport (53\%) and market information asymmetry by $13 \%$ of the respondents. Flea markets are not well advertised and where the farmers are not provided with transport to take their stock to the market. Less than $1 \%$ of the respondents (0.03) also ranked the loss of eggs third in the priority chart. This is 
because without eggs there are no chicks and many eggs get lost due to weather, snakes and predators. Lack of markets, predators and external parasites (mice and lice) for the produce were ranked fourth by $56 \%, 22 \%$ and $0.01 \%$ of the respondents respectively. Markets for indigenous chickens are lacking in Swaziland such that most of the chickens are returned from the markets. Predators in the form of wild cats and birds cause major loss of stock especially chicks. Without chicks farmers cannot have stock for sale and they can lack source of breeding stock. The low productivity of indigenous chickens' breeds was ranked fifth by $0.02 \%$ of the respondents. This low productivity results from the slow growth and maturity of indigenous chickens. Respondents $(0.01 \%)$ ranked traders who default to pay when given stock on credit fifth. Chicken theft was ranked eighth by $54 \%$ of the respondents. Stolen birds reduce sales, hence returns from the indigenous chickens industry. Fifty one percent of the farmers ranked the low prices earned from selling chickens ninth. This means that some farmers were not satisfied with market prices earned from chicken sales. Thirty eight percent of the farmers ranked mortalities of indigenous chickens tenth.

\section{Conclusions and Recommendations}

\section{Conclusions}

The study has shown that commercialisation of indigenous chickens was affected by provision of supplementary feed, prices of alternative products, number of chickens sold, and number of chickens consumed by the family. The study has also shown that farmers were constrained by lack of fencing material, lack of chicken housing and equipment and high disease incidences, lack of organised market, predators, low productivity of the chickens, lack of vaccinations to control diseases, slow growth and maturity of indigenous chickens, lack of credit to buy capital equipment, chicken theft, low market prices and high mortality rates of stock.

\subsection{Recommendations}

The results have shown that the capital costs and major constraints of indigenous chickens' production are housing and fencing. Provision of credit indigenous chickens famers would empower them provide appropriate housing and fencing for their chickens. This can improve the production of indigenous chickens. The results also indicated that feed costs were high. Farmers should be encouraged to form cooperatives so that they buy supplementary feed in bulk and take advantage of discounts. Land authorities, where possible must allocate land to organized farmers so that they can produce their own grain to feed their chickens. The Swaziland Government needs to resource the commercialisation programme, especially in formalizing the market instead of relying on the flea market.

\section{References}

Ary, D., Jacobs, L.C., \& Razavieh, A. (2002). Introduction to Research in Education. Belmont, CA: Wadsworth/Thomson Learning. 
Bravo-Ureta, B., \& Pinheiro, A. E. (1997). Technical, economic, and allocative efficiency in peasant farming: evidence from the Dominican Republic. The Developing Economies, 35, 48-67. http://dx.doi.org/10.1111/j.1746-1049.1997.tb01186.x

FAO. (2012). Desertification: UN Food Agency Highlights Progress in Swaziland Agriculture Initiative. Food and Agriculture Organisation of the United Nations. USA/UN. www.fao.org/, $12 / 10 / 2012$.

FAO. (2012). Village Chicken Production System in Rural Africa. FAO Corporate Document Repository. Food and Agricultural Organisation of the United Nations. www.fao.org/, 08/01/2013.

Fowler, F. J. (2002). Survey Research Methods. Thousand Oaks, CA: Sage Publications.

Goitom, A. (2009). Commercialisation of Smallholder Farming: Determinants and Welfare Outcomes. A Cross-sectional study in Enderta District, Tigrai, Ethiopia. Masters' Thesis. The University of Agder, Kristiansand, Norway. www.amazon.com/CommercializationSmallholder-Farming, 12/10/2012.

Magagula, C. (2012). Shaping Swaziland's Response to Food Insecurity: Indigenous Chickens. Techno-serve. Mbabane. Swaziland.

Martey, E., Ramatu, M., \& Kuwornu, J. (2012). Commercialisation of smallholder agriculture in Ghana: A Tobit regression analysis. African Journal of Agricultural Research.7(14),

2131-2141. http://www.academicjournals.org/AJAR

Masimula, J. M., (2004). Poultry Enterprise Budget and Farmers Perceptions towards the National Agricultural Marketing Board (NAMBOARD). Unpublished Research Project, University of Swaziland.

Masuku, M. B. (2011). An Analysis of the Broiler Supply Chain in Swaziland: A Case Study of the Manzini Region. Asian Journal of Agricultural Sciences 3(6), 492-499.

MOA. (2012). Poultry Production Report. Livestock Management Unit. Mbabane. Swaziland. www.gov.sz, 03/10/2012.

MOA. (2012). Livestock Marketing Unit. Mbabane. Swaziland. www.gov.sz, 05/10/2012.

MOA. (2012). Ministry of Agriculture Annual Report. Introduction to Indigenous Poultry Keeping - The Case of the Swazi Chicken. Mbabane. Swaziland.

Thompson, C. F. (2012). Swaziland Business Year Book. Government of Swaziland. Mbabane. Swaziland. www.swazibusiness.com, 03/10/2012.

Times of Swaziland (24 June, 2009). High Demand for Village Chickens. Article by Sipho Shongwe. Livestock and Technical Services. Ministry of Agriculture. Mbabane. Swaziland. Date accessed, from www.times.co.sz, 21/09/2012. 


\section{Al Macrothink}

Journal of Agricultural Studies

ISSN 2166-0379 2013, Vol. 1, No. 2

Times of Swaziland (29 April 2011). About 350 Indigenous Chickens Bought at Open Market. Article by Sifiso Sibandze. Ministry of Agriculture. Mbabane. Swaziland. www.times.co.sz, 21/09/2012.

Thwala, M. (2012). Analysing the value chain of the Family Poultry Subsector in the Lower Usuthu Project Area in Swaziland. SWADE. Siphofaneni. Swaziland.

Von Braun, J., Bouis, H., \& Kennedy, E. (1994). Conceptual Framework, In: Agricultural Commercialisation, Economic Development and Nutrition. Chapter 2. Von Braun and Kennedy (eds). The Johns Hopkins University Press, London. England.

\section{Copyright Disclaimer}

Copyright reserved by the author(s).

This article is an open-access article distributed under the terms and conditions of the Creative Commons Attribution license (http://creativecommons.org/licenses/by/3.0/). 